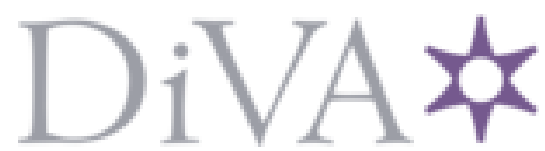

http://www.diva-portal.org

\title{
Postprint
}

This is the accepted version of a chapter published in Theoretical perspectives on family businesses.

Citation for the original published chapter:

Staffansson Pauli, K. (2015)

Gender theory and the family business.

In: Mattias Nordqvist, Leif Melin, Matthias Waldkirch and Gershon Kumeto (ed.), Theoretical perspectives on family businesses (pp. 191-210). Cheltenham: Edward Elgar Publishing https://doi.org/10.4337/9781783479665.00018

N.B. When citing this work, cite the original published chapter.

Permanent link to this version:

http://urn.kb.se/resolve?urn=urn:nbn:se:hj:diva-34246 


\section{Gender Theory and the Family Business}

\section{Karin Staffansson Pauli}

\section{Introduction}

The purpose of this paper is to present gender theory, with a focus on current and future applications in family business research. Family businesses serve as sites for the production of gender relations. According to Fletcher (2014), family business studies provide little understanding of how family business structures, settings and practices produce relations of power or asymmetry.

The role of women in family businesses is a topic of great interest because a growing number of women are entering family businesses today. There are some obstacles to their involvement, such as inconspicuousness, stereotyped roles, and certain aspects of succession and primogeniture (Jimenez, 2009). Family business can be seen as a distinct form of entrepreneurship. The dominant discourse of entrepreneurship is a form of masculinity, expressed in the media and perpetuated by researchers. The field of entrepreneurship is not alone in assuming a male experience as the norm. The same assumption is embedded in management studies and economics (Hamilton, 2013).

The field of gender theory began by studying the role of women and has only recently included theorising about men and masculinity. According to Ahl (2004, p.13), there are three main lines of thought in gender theory: women and men are essentially different, women and men are essentially similar, or talking about essences does not make any sense at all, that is to say, gender is socially constructed and a fleeting concept - 'doing gender' (West and Zimmerman, 1987). In other words, the content of what is regarded as female or male varies over time, place and social context. 
A common approach to the study of gender in family business situations is to consider 'gender as a variable', which maintains the categorisation of women and men as a relevant and unproblematic variable. Many analyses of family businesses that also address gender focus on feminist 'standpoint positions', giving voice to women's unique experiences (Fletcher, 2014). The use of 'standpoint positions’ means that gender is important in demonstrating that women possess particular insights and meanings that differ from those of the majority of men (Alvesson and Billing, 2009, p. 28). If gender, defined by Acker (1992, p. 250) as the "patterned, socially produced, distinctions between female and male, feminine and masculine”, is a key concept for understanding how people encounter encouragement, scepticism, support and suffering in family businesses, the gender issue in the family business should inspire reflection and sensitivity rather than emphasise the differences between women and men (Fletcher, 2014).

This paper is structured as follows: first, I present a brief overview of gender theory and its origins and fundamental assumptions. For a deeper overview, see Tanesani (1999) or Harding (1987). This overview is followed by a discussion of the connection between gender theory and the family business context. Finally, I present ideas for future research concerning gender theory in the family business context.

\section{Gender theory}

The field of gender theory, or feminist theory, began as the study of women. The concept of gender demonstrates how sex is socially constructed.

\subsection{Feminist theory}

One of the main points of feminist theory is that men are implicitly accepted as the norm and that women are the exception (Hearn and Parkin, 1983; Wahl, 1996). 
Feminism is broadly defined as the recognition of the unequal conditions of men and women and the desire to change this inequality.

The field of gender research developed during the 1980s and 1990s. A useful way of categorising the field is according to epistemological standpoints (Ahl, 2004). Alvesson and Billing (1999, 2009) distinguish between three perspectives: the first, which sees sex as an unproblematic variable, could be referred to as feminist empiricism; the second differentiates women from men as knowing subjects, including the feminist standpoint perspective; and the third is the post-structural perspective.

Feminist empiricism sees sex as a relevant and unproblematic variable. Sex is added as a category, with a focus on explaining discrimination against women as differences between the sexes; this is the dominant approach in management studies according to Ahl (2004). Feminist empiricism is justified when examining inequalities between women and men. To count women and men is efficient and a good starting point when conducting research. Inequalities might rest in the structures, but it is important to be aware that 'sex as a variable' research tends to reify and recreate gender differences.

From the feminist perspective, gender is seen as a basic organising principle in society, that is to say, women and men have different experiences and interests. The field of organisation research maintains that women do indeed manage and relate differently to work, and the field has been criticised for essentialism by inferring that certain traits go naturally with male and female bodies, according to Ahl (2004). Both the feminist empiricist perspective and the feminist standpoint perspective are occupied with the similarities or differences between men and women.

The third perspective, the post-structural perspective, questions the gender categories taken for granted by the 'sex as a variable' and feminist standpoint perspectives. The post-structural 
perspective builds on an understanding of gender as socially constructed, and the categories ‘women’ and ‘men’ are not taken for granted but are much more fluid, processual, uncertain and shifting. The post-structural perspective is a relational concept, not stable and socially constructed at each and every turn. Exclusive notions, such as 'woman', 'man', 'feminine' and 'masculine', are problematic because they imply a false unity, are not universal, and are dependent on different contexts (Alvesson \& Billing, 2009). In line with Ahl (2004), I conclude that gender should be regarded as a socially and discursively constructed phenomenon that is culturally, historically and locally embedded.

\subsection{Masculinity}

Masculinity has only recently been included as a part of gender theory, but to appreciate the interaction between women and men, it is also important to understand masculinity.

Kimmel (2006) notes that if men remain unaware of the centrality of gender in their lives, it will only help to perpetuate gender inequality. He argues that many feminist analyses have failed to resonate with men's own experiences. He suggests that this failure is not surprising because women have theorised about masculinity from their own point of view and from their experience of masculinity.

Furthermore, manhood is less about the drive for domination and more about the fear of other men’s domination - about having power or control over one another. Throughout history, men have been afraid that others will see them as less than manly, as weak, timid and frightened. Men have been afraid of not living up to what it means to be a man and afraid of failure. Men place importance on what other men think and do; men define their masculinity, not so much in relation to women, but in relation to each other. Kimmel (ibid) says that masculinity is largely a homosocial enactment and that homophobia is the fear of other men. 
Hegemonic masculinity was first introduced by Connell $(1987,2008)$ and refers to the dominant form of masculinity within the gender hierarchy, which, according to Acker (1990), plays an important part in legitimating organisational power. The term 'hegemony' refers to Antonio Gramsci’s (1967) analysis of class relations and is the dynamic that allows a group to maintain a leading position. Hegemony can only exist with acceptance from the subordinate groups. Although hegemonic masculinity subordinates other masculinities and femininities, it can also be challenged by them. In most Western societies today, hegemonic masculinity is associated with whiteness, heterosexuality, marriage, authority and physical toughness. However, hegemonic masculinity can also be questioned, for example, as a matter of context (Alvesson, 1998). Connell (ibid) also argues that to understand gender, we must be able to go beyond gender, that is to say, we cannot fully understand class, race or global inequities without considering gender. Connell argues, furthermore, that the gender order in the world still gives men more privileges than women.

Managerial masculinity is still centrally related to power, and the global corporate economy might be the setting for a new pattern of hegemonic masculinity - transnational business masculinity (Connell, 2008). It is a male-dominated world with a strong consciousness of change. Intense and stressful labour processes create multiple linkages among managers and subject them to mutual scrutiny, representing a force for gender conservatism. Economic globalisation has heightened men's insecurity about their place in the world and in the gender order. A manufacturing manager used to put capital to work in production and used to have a direct relationship with the production process, but Roper (1994) argues that the pattern of managerial masculinity has been superseded by professionalised, finance-oriented management. 
Ross-Smith and Huppatz (2010) argue that female and feminine dispositions have become currency in the masculinised field of management and have transformed into embodied cultural capital. Women's gender is a tangible asset but a limited currency, often doubleedged and perhaps best conceptualised as a tactical rather than a strategic resource. This thinking moves beyond the dichotomy of dominance and subordination.

\subsection{Gender in organisational studies}

Organisations are central economic institutions that produce goods and services. They can be big or small workplaces and provide a context for our working life. It is important to know which actors and groups set the agenda, what types of goals exist, and how relationships are formed between people.

Organisation theory has traditionally neglected gender issues. Calás and Smircich (1996) argue that we would create a more inclusive field of organisational studies if feminist theories were not just treated as a women’s issue. They say that organisational scholarship has primarily comprised literature written by men, for men, and about men. According to Alvesson and Billing (2009, p. 5), a gender perspective on organisations will give us important insights into how organisations function, for example, in terms of leadership, strategy, organisational culture, groups, communication, ethics and corporate social responsibility. In other words, a gender perspective on organisations goes beyond questions about positive and negative outcomes from gender patterns for the careers and work situations of women and men. Alvesson and Billing (2009, p. 1) also argue that two strong motives for taking an interest in gender and organisation are injustice and business management. From a management perspective, there are reasons to be concerned about the ineffective uses of human resources arising from the gender order, particularly that women in general have lower wages, even within the same occupation and at the same level, experience more unemployment, take more responsibility for unpaid labour, are strongly underrepresented at 
higher positions in organisations, and have less autonomy and control over work and lower expectations of promotion.

The power dimension must be included in gender theory, and Hirdman (1992) states that the gender order is a pattern one can see when looking at society on a general level. There are two primary logics in the gender order: segregation and hierarchisation. Segregation in this context means the stereotypical segregation between women and men and between femininity and masculinity. Hierarchisation means the creation of a gender-based hierarchy with men at the top; it also means that men and masculinity are ascribed a higher value than women and femininity. There is often male domination and female subordination.

Of fundamental interest to the gender tradition is the systematic organisation of work into gendered spheres. Gendered divisions of labour are sources of female exploitation and mechanisms for proliferating the existing structures. Gender studies engage in documenting the nature of the gendered divisions of labour, in estimating whose interest these divisions serve, and in assessing how they may be redrawn.

The gendered divisions of labour can be found between waged and unwaged labour, within waged labour, and within unwaged labour. The most striking gendered division of labour has been between the overwhelming employment of men in salaried/waged employment and the disproportionate number of women in unpaid work. With the rise of predominantly male professionals running enterprises, women's unpaid work has also grown to include activities intended to support the male breadwinner in the additional social aspects of his job. Numbers, power and the opportunity structure all contribute to the way that women (and men) come to view their worth within organisations (Kanter, 1977). Kanter was ground-breaking in recognising structure as the explanation or influence for pursuing a career in organisations. 
Gender is produced by and in organisations in multiple ways, the most obvious being through the construction and maintenance of gendered divisions of work (Acker, 1990).

In recent decades, a processual view on gender has been increasingly collated under the overall term ‘doing gender’ (Korvajärvi, 2003; Kvande, 1999, 2003; Andersson, 2003; Vänje, 2005).

Acker $(1990,1992)$ identifies four different interacting processes as points of entry, ways into the on-going flow of actions and interactions that constitute organisational life; they are analytically distinct, but parts of the same reality. Gendering may produce gender-explicit or gender-neutral practices and occur through concrete organisational activities. Gendering processes also have class and racial implications. These practices are supported by the assumption that work is separate from the rest of life and that it has first claim on the worker.

The first point of entry identified by Acker is through the ordinary, often daily, procedures and decisions that, while doing the work of the organisation, also segregate, manage, control, and construct hierarchies involving gender, class and race. All of the following promote gender divisions: division of labour, permitted behaviour, locations in physical space, and power, including the institutionalised means of maintaining divisions in the structures of labour markets, the family, and the state. For example, men are almost always in the highest positions of organisational power. Managerial decisions often initiate gender divisions, and organisational practices maintain them.

The second process is the construction of symbols and images that explain, express, reinforce, or sometimes oppose those divisions. These have many sources or forms: language, ideology, popular and high culture, dress, the press, and television. The image of the top manager or the business leader is an image of successful, forceful masculinity. The organisation itself is often defined through metaphors for a certain type of masculinity. These men are portrayed as lean, 
mean, aggressive, goal-oriented, efficient, and competitive, but rarely as empathetic, supportive, kind, or caring. Organisational participants actively create these images in their efforts to construct organisational cultures that contribute to competitive success.

The third set of processes produce gendered social structures, including those in organisations. These are interactions between women and men, between women and women, and between men and men, including all of those patterns that enact dominance and submission. Men are the actors and women are the emotional support. Interactions may be between supervisors and subordinates, between co-workers, or between workers and customers, clients or other outsiders. Interactions are part of the fabric of organisations, and the production of gender often lies within those activities that constitute the organisation itself.

Fourthly, these processes help to produce gendered components of individual identity, which in an organisation may include consciousness of the existence of the other three aspects of gender discussed above, such as the following: choice of appropriate work, language use, clothing, and presentation of self as a gendered member of the organisation. This presentation includes creating the correct gendered persona and hiding perceived socially unacceptable aspects of one’s life, such as homosexuality.

Kvande (1999) explores how female graduate engineers construct femininities in male dominated organisations. Different versions of femininity are constructed through associations with similarities or differences. The graduate engineering profession is closely associated with hegemonic masculinity, not least by the strong representation of technology. According to Kvande (ibid), women either choose to construe themselves as more or less different from men or to be recognised as a woman. 


\section{Gender theory in family business research}

Surprisingly little research has been done on examining the role of the woman in family businesses, as the woman in family is an important role. Studies of gender in the family business are beginning to appear, but those focused on the role and involvement of women in family businesses are still fragmentary, and few empirical studies have been conducted (Jiminez, 2009).

The theorising in Entrepreneurship has much relevance for family business studies. In the last decade, some attention has been paid to theorising about gender in entrepreneurship (Marlow, 2002; Bruni, Gherardi \& Poggio, 2005; Ahl, 2006). Gender studies in entrepreneurship research have largely focussed on the experiences of women. To address the inconspicuousness of women in entrepreneurship, according to the research of Hamilton (2013), one solution has been to work harder to discover differences and the potentially unique contribution of women entrepreneurs. Swan (2006) argues that instead of understanding the unique experiences of women and their so-called natural, socialised, feminine styles, it would be better to adopt a more discursive and post-structural approach.

To look into contributions published on women and family businesses, Jimenez (2009) reviewed 48 different articles, 23 books and 3 doctoral dissertations published since 1985. Her review shows an increase in the incorporation and participation of women in family businesses. The first contribution she singled out is an analysis of the difficulties or obstacles that women face when joining their family firms, particularly in terms of the lack of recognition for their work, exemplified by inconspicuousness, emotional leadership and succession and primogeniture. The second contribution she noted is a recent trend toward authors becoming more positive, discussing the opportunities or advantages that family firms can offer women. She identifies two different topics concerning the positive aspects of being a 
woman in a family business: Women's professional careers in the family firm and Running the family firm.

Two of the difficulties and obstacles of being a woman in a family business are women's inconspicuousness and the fact that gender stereotypes exist in society. Occupational segregation, underrepresentation in upper-level management, and expectations about traditional family roles can restrict women to jobs in certain industrial sectors and can affect their motivation and goals for their business ventures (Aldrich, 1989). Women who work in family businesses face issues similar to those faced by all businesswomen (Starr \& Yudkin, 1996), but they also face problems that are unique to their situation.

Some authors use the term emotional leadership when referring to women in family firms (Lyman, 1988; Salganicoff, 1990; Ward, 1987). According to these authors, women are adept at interpreting the behaviour of one family member toward another and at ensuring that people’s feelings are considered. According to Salganicoff (1990), women have certain gender characteristics that make them better suited to the roles of caretaker, peacemaker and conflict solver, roles that are fundamental for the success and survival of the family firm. Women, though inconspicuous, can occupy an important leadership role both in the family and in the firm.

Daughters often join the family firm at times of crisis or when their father has no sons (Curimbaba, 2002; Dumas, 1992, 1998). Many family firms use the primogeniture criterion, where the firstborn male child will take over the family firm, thus freeing fathers from the disagreeable task of comparing and choosing between their children.

Positive aspects of making a professional career in the family firm are analysed by Cole (1997), and her findings contradict earlier studies. Cole concludes that women have not been held back because of their gender and have not come up against the feared 'glass ceiling'. The 
women in the study also had a positive view about their careers. Women’s access to sectors traditionally regarded as 'masculine', for example the construction industry, have also been made possible by advantages, such as the introduction of flexible schedules, which some authors assert allow women to combine their professional responsibilities with child care (Dumas, 1992, 1998; Frishkoff \& Brown, 1993; Haynes, Avery \& Hunts, 1999; Lyman et al., 1985).

According to Dumas (1998), the family firm is an ideal environment for preparing daughters for leadership, in the sense that the father acts as a coach and a natural mentor.

Salganicoff (1999) says that family firms are one of the few areas that offer women real opportunities to reach the highest positions in business, positions such as president, vicepresident, member of the board of directors, and so on. Vera and Dean (2005) discuss the problems that daughters face once the succession is completed and they have taken over the running of the firm. An interesting finding of this work is that when the daughters have previous experience outside of the family firm, their credibility appears to be greater as does their self-confidence. It was also found that the father precisely defines his daughter's position in the firm.

Salganicoff (1990) argues that women possess particular characteristics and qualities that are vital for the success of the company and that women are a valuable resource, including as spouses (Poza and Messer, 2001). Francis (1999) suggests that most women have many of the skills and attributes that experts judge to be necessary for the success of future managers and leaders. These skills include the ability to multitask and the ability to trust instinct and intuition rather than just analysis and rationality.

Research on succession planning in family businesses has largely neglected issues linked to owner gender, but Harveston et al. (1997) examine the extent to which differences are evident 
between male- and female-led family businesses in the succession planning process. The results confirm that there are similarities and differences between males and females in the determinants of succession planning. One of the most influencing factors behind the choice of a woman as a future successor is that the firm currently has a female boss. Firms previously run by women chose female successors 31 per cent of the time compared with 7 per cent of the firms previously run by men (Allen \& Langowitz, 2003).

Often in family business research, as described above, the dominant approach is to conceive of gender in terms of limited male/female distinctions rather than by reframing family business through critical positions with the aim of reflection and sensitivity towards gender issues in terms of the socially constituted patterns that are produced through male/female, masculine/feminine distinctions (Fletcher, 2014, p 141).

Pettersson (2008) states that the gender perspective also contributes to entrepreneurial research in that it shows diverse ways of being an entrepreneur and a multitude of ways to run a business, without being restricted to arrant masculinity that builds on technical innovation, risk-taking or full time employment, with a huge ambition for growth. In line with the diversity in family businesses and believing that theorising in entrepreneurship has much relevance for family business, there is a link between gender and entrepreneurship and gender and family businesses.

Bjursell and Melin (2011) argue for a shift away from focussing on the entrepreneur as a masculine concept towards understanding entrepreneurship as a combination of the masculine and the feminine. They use stories about women entering the family business and offer a new perspective on entrepreneurial identity as a narrative construction. This field of study is relevant because others have also concluded that increasing numbers of women are entering family businesses and taking up leadership positions (Barrett \& Moores, 2009; Harveston et 
al., 1997). The move from the family context to the business context has an impact on the individual woman's identity process (Bjursell \& Melin, 2011).

Based on gendered expectations, women in the family business can find themselves in situations where they are not considered to be potential leaders or owners by the older generation. According to Bjursell and Melin (2011), in family-owned firms, the contexts influencing the construction of meaning and identity among family members are family, business, and gender.

My primary finding is that gender in family businesses has so far primarily focussed purely on women from a feminist 'standpoint position', without applying any critical gender theory. Nilson's chapter about critical theory in this book offers a deeper overview.

Table 2. Articles of relevance about gender and family business research

\section{Ideas for future research}

There are several topics that could be applied to gender theory in family business research. Jiminez (2009), for example, presents various topics and research questions, such as women's insignificance in the family business, the supposition of emotional leadership made by women, the importance of succession and primogeniture and how it affects the family business, how a professional career in the family firm is made, and how to run the family firm, what is involved and why.

When reviewing the literature concerning gender in family businesses, I identified a number of gaps that could be filled to generate further understanding of the gender issue, in particular, the context. Gender aspects most likely vary according to where the family business is 
situated. Is it in a western society or not? What type of business or industry is it? What types of customers does the business serve? What gendered processes are there? How are processes linked between the family and the business? (Figure 1)

Because the dominant discourse of entrepreneurship is a form of masculinity and, as Hamilton (2013) states, this is perpetuated by academic research, future research must investigate the theory of male-dominated entrepreneurship and challenge the primary discourse that women are inconspicuous.

When reviewing the literature, I noticed that many articles proposed the view that women possess particular traits. Most of the articles use the essentialist view on women and men, which might constrain the ability to develop gender issues in the family business field. There also appears to be a bias towards heterosexual and nuclear family discourse in the field.

I argue, therefore, that it would be meaningful to apply the theoretical model of four different gendered interaction processes proposed by Ackers $(1990,1992)$ - division, images, interaction and identity - in the family business context by incorporating the organisation gendering processes within the family gendering processes. Ackers' (ibid) ideas are supported by the assumption that work is separated from everyday life and that work has first claim on the worker. It would, therefore, be fruitful to examine the processes in the family business situation because the gendering processes in business and organisation overlap the family processes by virtue of the fact that work and family are not separated.

I also concur with the ideas of Kvande (2002) described earlier, about examining how women construct femininity in family businesses because the dominant discourse in family business is a form of masculinity. It would be interesting to examine whether different versions of femininity are constructed through associations with similarities or differences with men in 
family businesses in various industries. How are women choosing to promote themselves? Do they see themselves as more or less different from men or as recognisable as women?

Figure 11.1. Interaction of gender processes in family and business

According to Barrett and Moores (2009), there are several reasons why understanding more about women leaders of family-controlled businesses can help the understanding of family business in general. Firstly, they are increasingly being recognised as the source of many new entrepreneurs and secondly, women are, at present, more likely to achieve leadership of their family firms.

\subsection{Methods}

There are several qualitative methods that can be used together with gender theory in family business research, such as ethnographic studies, in-depth interviews, comparative case studies, and narratives. To obtain a broader picture, mixed methods can also be used. Mixed methods means integrating quantitative and qualitative research within a single project (Bryman \& Bell, 2007).

By applying Acker’s (1990, 1992) and Kvande’s (2002) ideas of gendered processes and studying how women negotiate femininity, I would start by counting or mapping the numbers of women and men in the organisation and thereafter conduct an ethnographic study and/or perform interviews to secure an in-depth understanding of gender identity and interactions in different family businesses. To be able to apply all of the four different gendered processes division, images, interaction and identity - there also must be information about the images or 
symbols that represent the firm, including sales material or public material, such as annual reports.

\subsection{Expanding family business research}

I propose that it is possible for gender theory to expand research into family businesses. I argue that using gender theory would be more inclusive, and I also advocate using gender theory intertwined with Fletcher's critical theory approach (2014), which says that there is little understanding of how family business structures, settings and practices produce relations of power or asymmetry. It would be interesting to look into the gendered processes in family businesses and also to question the norms.

Fletcher (2014, p. 142) argues that when linking issues of family and gender, researchers face a number of analytical and epistemological challenges. One could expand on traditional liberal/sociological feminist perspectives that begin with the premise that male/female distinctions or gender differences inspire social change, or alternatively, one could challenge male/female distinctions as valid points of departure (Alvesson and Billing, 2009) and work towards an alternative conceptualisation that sees putting men and women into categories as ambiguous, arbitrary and contradictory, indeterminate and dynamic. This alternative would challenge the notion of inconspicuous women in family businesses but would also more closely examine how family business contexts are sites for the production of gender relations (Alvesson and Billing, 2009).

The research field of family business could improve its engagement with conceptualising gender and, as Hamilton (2103) and Wharton (2005) argue, more could be done in the entrepreneurial field to incorporate a more theoretically sophisticated understanding of gender. 
Gender in family business theory, as in entrepreneurship research, should focus more on the aim "to study how gender is accomplished rather than study what it is” (Ahl, 2004, p. 192). Last but not least, future research should focus on understanding family business as a combination of the masculine and the feminine (Bjursell \& Melin, 2011).

I advocate investigating a single industry, for example the male dominated construction industry or the real estate industry, and studying different family businesses that are inherited and led by women. What strategies do they use to pursue their career? How do they negotiate femininity? What is the link between family and business? Does this case differ from that of the non-family business? The ideas of both Acker $(1990,1992)$ and Kvande (2003), described above, could be used as tools in the research.

To conclude, it is possible that gender research in the family business context could expand the development of gender theory as well because the focus, especially in the field of gender and organisation, has been on the boundaries of the organisation and the public sphere of gender and not on the private sphere and the interaction with the private life. It would be interesting to further explore gender and its interaction with family and business. 


\section{References}

Acker, J. (1990), 'Hierarchies, jobs, bodies: a theory of gendered organizations', Gender and Society, 4 (2), 139-58.

Acker, J. (1992), ‘Gendering organizational theory’, in Mills, A. and Tancred, P. (eds), Gendering Organizational Analysis, London: Sage, pp. 248-60.

Ahl, H. (2004), The Scientific Reproduction of Gender Inequality- A Discourse Analysis of Research Texts on Women's Entrepreneurship, Malmö, Sweden: CBS, Liber.

Ahl, H. (2006), 'Why research on women entrepreneurs needs new directions', Entrepreneurship Theory and Practice, 30 (3), 595-621.

Aldrich, H. (1989), ‘Networking among women entrepreneurs’, in Hagan, O., Rivchun, C. and Sexton, D. (eds), Women-owned Businesses 8, New York: Praeger, pp. 103-32.

Allen, I. E. and Langowitz, N. S. (2003), Women in Family-owned Businesses, Boston, MA: MassMutual Financial Group and Center for Women’s Leadership at Babson College.

Alvesson, M. (1998), 'Gender relations and identity at work: a case study of masculinities and femininities in an advertising agency’, Human Relations, 51 (8), 969-1005.

Alvesson, M. and Billing, Y. D. (1999), Kön och organisation, Lund, Sweden: Studentlitteratur.

Alvesson, M. and Billing, Y. D. (2009), Understanding Gender and Organizations, London: Sage.

Andersson, S. (2003), Ordande praktiker. En studie av status, homosocialitet och maskuliniteter utifrån två närpolisorganisationer. Stockholm: Pedagogiska Institutionen, Stockholms Universitet. 
Barrett, M. and Moores, K. (2009), 'Spotlights and shadows: preliminary findings about the experiences of women in family business leadership roles', Journal of Management and Organization, 15 (3), 363-77.

Bjursell, C. and Melin, L. (2011), 'Proactive and reactive plots: narratives in entrepreneurial identity construction', International Journal of Gender and Entrepreneurship, 3 (3), 218-35.

Bruni, A., Gherardi, S. and Poggio, B. (2005), Gender and Entrepreneurship: An Ethnographic Approach, New York: Routledge.

Bryman, A. and Bell, E. (2007) Business Research Methods, 2nd edn, New York: Oxford University Press.

Cadieux, L., Lorrain, J. and Hugron, P. (2002), 'Succession in women-owned family businesses: a case study', Family Business Review, 15 (1), 17-30.

Calás, M. and Smircich, L. (1996) ‘From "the woman’s" point of view: feminist approaches to organization studies', in Clegg, S., Hardy, C. and Nord, W. (eds), Handbook of Organization Studies, London: Sage, pp. 218-57.

Cole, P. M. (1997), ‘Women in family business’, Family Business Review, 10 (4), 353-71.

Connell, R. W. (1987), Gender and Power, Stanford, CA: Stanford University Press.

Connell, R. W. (2008), Maskuliniteter, Göteborg, Sweden: Bokförlaget Daidalos AB.

Curimbaba, F. (2002), ‘The dynamics of women’s roles as family business managers’, Family Business Review, 15 (3):239-52.

Danes, S. M. and Olson, P. D. (2003), ‘Women’s role involvement in family businesses, business tensions, and business success', Family Business Review, 16 (1), 53-67. 
Danes, S., Haberman, H. and McTavish, D. (2005), 'Gendered discourse about family business', Family Relations, 54 (1), 116-30.

Dumas, C. (1989), 'Understanding of father-daughter and father-son dyads in family-owned businesses’, Family Business Review, 2 (1), 31-46.

Dumas, C. (1992), ‘Integrating the daughter into family business management’, Entrepreneurship Theory and Practice, 16 (4), 41-56.

Dumas, C. (1998), 'Women’s pathways to participation and leadership in the family-owned firm', Family Business Review, 11 (3), 219-28.

Dumas, C., Dupuis, J. P., Richer, F. and St-Cyr, L. (1995), 'Factors that influence the next generation's decision to take over the family farm', Family Business Review, 8 (2): 99-120.

Duxbury, L., Higgins, C. and Lee, C. (1994), 'Work-family conflict: a comparison by gender, family type, and perceived control', Journal of Family Issues, 15 (3), 449-66.

Fletcher, D. (2014), 'Family business inquiry as a critical social science', in Melin, L., Nordqvist, M. and Sharma, P. (eds), The SAGE Handbook of Family Business 1st edn, Thousand Oaks, CA: SAGE, pp. 137-54.

Fletcher, J. K. (2004), ‘The paradox of post heroic leadership: an essay on gender, power and transformational change', Leadership Quarterly, 15(5), 647-61.

Francis, A. E. (1999), Their Daughter Also Rises: How Women Overcome Obstacles and Advance in the Family-owned Business, San Francisco, CA: Rudi.

Frishkoff, P. A. and Brown, B. M. (1993), 'Women on the move in family business', Business Horizons, 36 (2), 66-70. 
Galiano, A. M. and Vinturella, J. B. (1995), 'Implications of gender bias in the family business', Family Business Review, 8 (3), 177-88.

Garcia-Alvarez, E., Lopez-Sintas, J. and Gonzalvo, P. S. (2002), ‘Socialization patterns of successors in first to second generation family businesses’, Family Business Review, 15 (3),189-203.

Gramsci, A. (1967), En kollektiv intellektuell, Staffanstorp, Sweden: Cavefors, Uddevalla.

Haberman, H. and Danes, S. M. (2007), 'Father-daughter and father-son family business management transfer comparison: family FIRO model application’, Family Business Review, 20 (2), 16384.

Hamilton, E. (2013), 'The discourse of entrepreneurial masculinities (and femininities)', Entrepreneurship and Regional Development, 25 (1-2), 90-99.

Harding, S. (ed.) (1987), Feminism and Methodology, Bloomington, IN: Indiana University Press.

Harveston, P. D., Davies, P. S. and Lyden, J. A. (1997), 'Succession planning in family business: the impact of owner gender’, Family Business Review, 10 (4), 373-96.

Haynes, D. C., Avery, R. J. and Hunts, H. J. (1999), 'The decision to outsource child care in households engaged in a family business', Family Business Review, 12 (3), 269-82.

Hearn, J. and Parkin, W. (1983), ‘Gender and organizations: a selective review and critique of a neglected area', Organization Studies, 4 (3), 219-42.

Hirdman, Y. (1992), Den socialistiska hemmafrun och andra kvinnohistorier, Stockholm: Carlssons Förlag.

Jimenez, R. M. (2009), 'Research on women in family firms - current status and future directions', Family Business Review, 22 (1), 53-64.

Kanter, R. (1977), Men and Women of the Corporation, New York: Basic Books. 
Kimmel, M. (2006), Manhood in America, New York: Oxford University Press.

Korvajärvi, P. (2003), ““Doing gender” - theoretical and methodological considerations’, in Gunnarssons, E. et al. (eds) Where Have All the Structures Gone? Doing Gender in Organizations, Examples from Finland, Norway and Sweden, report no. 33, Stockholm: Centre for Women’s Studies, Stockholm University.

Kvande, E. (1999), ““In the belly of the beast”: constructing femininities in engineering’, Organizations’ European Journal of Women’s Studies, 6 (3), 305-28.

Kvande, E. (2002), 'Doing masculinities in organizational restructuring', NORA - Nordic Journal of Feminist and Gender Research, 10 (1), 16-25.

Kvande, E. (2003), 'Doing gender in organizations - theoretical possibilities and limitations', in Gunnarssons, E. et al. (eds), Where Have All the Structures Gone? Doing Gender in Organizations, Examples from Finland, Norway and Sweden, report no. 33, Stockholm: Centre for Women’s Studies, Stockholm University.

Lewis, J. and Morgan, D. (1994), 'Gendering organizational change: the case of Relate, 1948-1990’, Human Relations, 47 (6), 641-63.

Lyman, A. R. (1988), 'Life in the family circle’, Family Business Research, 1 (4), 383-98.

Lyman, A. R., Salganicoff, M. and Hollander, B. (1985), 'Women in family business: an untapped resource', SAM Advanced Management Journal, 50 (1), 46-9.

Marlow, S. (2002), 'Women and self employment: a part of apart from theoretical construct', The International Journal of Entrepreneurship and Innovation, 3 (2): 83-91.

Melin, L. (2008), ‘Ägarskiften genom arv eller köp - en möjlighet för kvinnor’, in Larsson, P., Göransson, U. and Lagerholm, M. (eds), Sesam öppna dig! Perspektiv på kvinnors företagande, Stockholm: Vinnova. 
Mulholland, K. (1996), 'Gender and property relations within entrepreneurial wealthy families’, Gender, Work and Organisation, 3 (2), 78-102.

Pettersson, K. (2008), 'Hur påverkas kvinnors företagande av familj och privatliv?’, in Larsson, P., Göransson, U. and Lagerholm, M. (eds), Sesam öppna dig! Perspektiv på kvinnors företagande, Stockholm: Vinnova.

Poza, E. J. and Messer, T. (2001), 'Spousal leadership and continuity in the family firm', Family Business Review, 14 (1), 25-36.

Roper, M. (1994), Masculinity and the British Organization Man Since 1945, Oxford: Oxford University Press.

Ross-Smith, A. and Huppatz, K. (2010), 'Management, women and gender capital’, Gender, Work and Organization, 17 (5), 547-66.

Salganicoff, M. (1990), ‘Women in family businesses: challenges and opportunities’, Family Business Review, 3 (2), 125-37.

Starr, J. and Yudkin, M. (1996), Women Entrepreneurs: A Review of Current Research, Wellesley, MA: Center for Research on Women.

Swan, E. (2006), 'Gendered leadership and management development: therapeutic cultures at work', in McTavish, D. and Miller, K. (eds), Women in Leadership and Management, Cheltenham, UK and Northampton, MA, USA: Edward Elgar.

Tanesani, A. (1999), An Introduction to Feminist Epistemologies, Malden: Blackwell.

Vera, C. F. and Dean, M. A. (2005), 'An examination of the challenges daughters face in family business succession’, Family Business Review, 18 (4), 321-46. 
Vänje, A. (2005), Knäcka koderna: praxis kring kön, industriell organisation och ledarskap, Luleå, Sweden: Luleå tekniska universitet.

Wahl, A. (1996), 'Molnet - att föreläsa om feministisk forskning', Kvinnovetenskaplig tidskrift, 3-4, 31-44.

Ward, J. L. (1987), Keeping the Family Business Healthy: How to Plan for Continuing Growth, Profitability, and Family Leadership, San Francisco, CA: Jossey-Bass.

West, C. and Zimmerman, D. (1987), 'Doing gender’, Gender and Society, 1 (2), 125-51. 


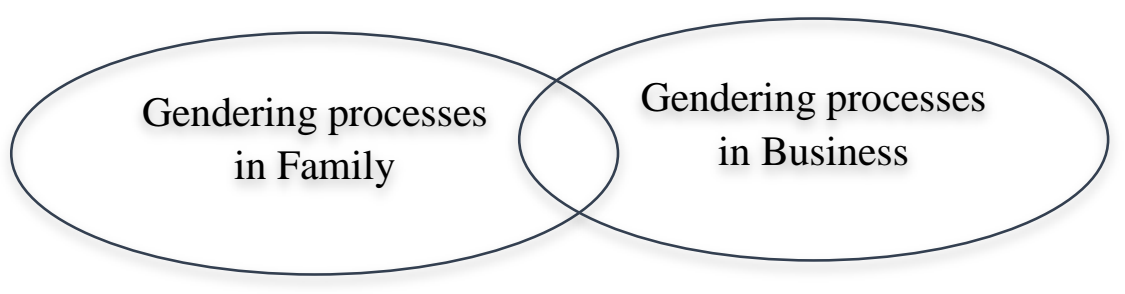

Figure 11.1: Interaction of processes of gender in family and business

Table 11.1: Articles of relevance about gender and family business research

\begin{tabular}{|c|c|c|c|}
\hline Authors & Journal & Title & Main findings/conclusions \\
\hline $\begin{array}{l}\text { Bjursell. and } \\
\text { Melin (2011) }\end{array}$ & $\begin{array}{l}\text { International } \\
\text { Journal of Gender } \\
\text { and } \\
\text { Entrepreneurship }\end{array}$ & $\begin{array}{l}\text { Proactive and reactive } \\
\text { plots: narratives in } \\
\text { entrepreneurial identity } \\
\text { construction. }\end{array}$ & $\begin{array}{l}\text { A shift from focussing on the entrepreneur as a masculine concept } \\
\text { towards understanding entrepreneurship as a combination of the } \\
\text { masculine and the feminine. }\end{array}$ \\
\hline $\begin{array}{l}\text { Cadieux, } \\
\text { Lorrain and } \\
\text { Hugron (2002) }\end{array}$ & $\begin{array}{l}\text { Family Business } \\
\text { Review }\end{array}$ & $\begin{array}{l}\text { Succession in Women- } \\
\text { Owned Family } \\
\text { Businesses: A case } \\
\text { study. }\end{array}$ & $\begin{array}{l}\text { A case study of four women who own and run family businesses in the } \\
\text { manufacturing sector, and who have shared the management of their } \\
\text { organisations with their successors for at least three years. }\end{array}$ \\
\hline Cole (1997) & $\begin{array}{l}\text { Family Business } \\
\text { Review }\end{array}$ & $\begin{array}{l}\text { Women in Family } \\
\text { Business. }\end{array}$ & $\begin{array}{l}\text { Women and other family members were interviewed on how gender- } \\
\text { related issues affected their work. }\end{array}$ \\
\hline $\begin{array}{l}\text { Curimbaba } \\
(2002)\end{array}$ & $\begin{array}{l}\text { Family Business } \\
\text { Review }\end{array}$ & $\begin{array}{l}\text { The Dynamics of } \\
\text { Women's Roles as } \\
\text { Family Business } \\
\text { Managers. }\end{array}$ & $\begin{array}{l}\text { Twelve open-ended, in-depth interviews with female heirs in a variety of } \\
\text { family businesses. Three groups were formed to describe the daughters' } \\
\text { experiences: inconspicuous, professional and anchor. }\end{array}$ \\
\hline $\begin{array}{l}\text { Danes and } \\
\text { Olson }(2003)\end{array}$ & $\begin{array}{l}\text { Family Business } \\
\text { Review }\end{array}$ & $\begin{array}{l}\text { Women's role } \\
\text { involvement in family } \\
\text { businesses, business } \\
\text { tensions, and business } \\
\text { success. }\end{array}$ & $\begin{array}{l}\text { A study of } 392 \text { family-business-owning couples where the husband is } \\
\text { the business owner, with the purpose of examining the work } \\
\text { involvement of the wife in the business, the business tensions, and the } \\
\text { impact of those tensions on family business success. }\end{array}$ \\
\hline $\begin{array}{l}\text { Danes, } \\
\text { Haberman and } \\
\text { McTavish } \\
(2005)\end{array}$ & $\begin{array}{l}\text { Family Business } \\
\text { Review }\end{array}$ & $\begin{array}{l}\text { Gendered Discourse } \\
\text { about Family Business, } \\
\text { Family Relations, } \\
\text { 54(1):116-130. }\end{array}$ & $\begin{array}{l}\text { Language patterns of family business owners were explored by } \\
\text { identifying discourse styles, and emphasised ideas in four presenting } \\
\text { contexts: business, family, intersection of family and business, and } \\
\text { business success. }\end{array}$ \\
\hline Dumas (1989) & $\begin{array}{l}\text { Family Business } \\
\text { Review }\end{array}$ & $\begin{array}{l}\text { Understanding of } \\
\text { Father-daughter and } \\
\text { Father-son Dyads in } \\
\text { Family-owned } \\
\text { Businesses. }\end{array}$ & $\begin{array}{l}\text { The article compares the results of an empirical study of the father- } \\
\text { daughter dyad in family-owned businesses with the literature on the } \\
\text { father-son dyad in family-owned businesses, and stresses the similarities } \\
\text { and differences between the two. }\end{array}$ \\
\hline $\begin{array}{l}\text { Dumas, Dupuis, } \\
\text { Richer and } \\
\text { St-Cyr (1995) }\end{array}$ & $\begin{array}{l}\text { Family Business } \\
\text { Review }\end{array}$ & $\begin{array}{l}\text { Factors that Influence } \\
\text { the Next Generation's } \\
\text { Decision to Take Over } \\
\text { the Family Farm. }\end{array}$ & $\begin{array}{l}\text { An in-depth, descriptive, and explanatory study of thirty next } \\
\text { generation family farm members indicates specific factors critical to } \\
\text { their decision to pursue the family farm succession. }\end{array}$ \\
\hline Dumas (1998) & $\begin{array}{l}\text { Family Business } \\
\text { Review }\end{array}$ & $\begin{array}{l}\text { Women's Pathways to } \\
\text { Participation and } \\
\text { Leadership in the } \\
\text { Family-Owned Firm. }\end{array}$ & $\begin{array}{l}\text { A study of } 702 \text { women in family-owned firms in Canada has identified } \\
\text { paths to participation and leadership taken by women in family-owned } \\
\text { firms. Some of the key factors contributing to participation and } \\
\text { leadership are presented in a descriptive framework. Implications of this } \\
\text { study for practice and research are presented. }\end{array}$ \\
\hline $\begin{array}{l}\text { Duxbury, } \\
\text { Higgins and Lee } \\
(1994)\end{array}$ & $\begin{array}{l}\text { Journal of Family } \\
\text { Issues }\end{array}$ & $\begin{array}{l}\text { Work-family conflict: } \\
\text { A comparison by } \\
\text { gender, family type, } \\
\text { and perceived control. }\end{array}$ & $\begin{array}{l}\text { Examines the relationships between the dependent variable of work- } \\
\text { family conflict and the independent variables of gender, family type, } \\
\text { and perceived control. The sample consisted of } 1989 \text { single-parent and } \\
\text { dual-income employees with children aged from } 6 \text { to } 12 \text {. }\end{array}$ \\
\hline Fletcher (2004) & $\begin{array}{l}\text { Leadership } \\
\text { Quarterly }\end{array}$ & $\begin{array}{l}\text { The Paradox of Post } \\
\text { Heroic Leadership: An }\end{array}$ & $\begin{array}{l}\text { Explores a number of paradoxes embedded in new, commonly called } \\
\text { 'postheroic models' of leadership. It argues that, although these models } \\
\text { emphasise leadership as a social process dependent on social networks of }\end{array}$ \\
\hline
\end{tabular}




\begin{tabular}{|c|c|c|c|}
\hline & & $\begin{array}{l}\text { Essay on Gender, } \\
\text { Power and a } \\
\text { Transformational } \\
\text { Change. }\end{array}$ & $\begin{array}{l}\text { influence, the concepts are often presented as gender and, to a lesser } \\
\text { degree, power-neutral, not only in theory, but in practice. 'Doing } \\
\text { gender', 'doing power' and 'doing leadership' are linked. }\end{array}$ \\
\hline $\begin{array}{l}\text { Galiano and } \\
\text { Vinturella } \\
(1995)\end{array}$ & $\begin{array}{l}\text { Family Business } \\
\text { Review }\end{array}$ & $\begin{array}{l}\text { Implications of gender } \\
\text { bias in the family } \\
\text { business. }\end{array}$ & $\begin{array}{l}\text { The prevalence of bias towards females and some underlying } \\
\text { perceptions in regard to gender within the context of the family business } \\
\text { are explored in this article. The implications of gender bias for the well- } \\
\text { being of family businesses are analysed, with particular reference to the } \\
\text { issue of succession planning. Women's changing professional and family } \\
\text { roles are also examined. }\end{array}$ \\
\hline $\begin{array}{l}\text { Garcia-Alvarez, } \\
\text { Lopez-Sintas } \\
\text { and Gonzalvo } \\
(2002)\end{array}$ & $\begin{array}{l}\text { Family Business } \\
\text { Review }\end{array}$ & $\begin{array}{l}\text { Socialization Patterns } \\
\text { of Successors in First to } \\
\text { Second Generation } \\
\text { Family Businesses. }\end{array}$ & $\begin{array}{l}\text { The article focusses on the socialisation of potential successors in family } \\
\text { business and attempts to relate this process to values that founders } \\
\text { intend to convey to the next generation. }\end{array}$ \\
\hline $\begin{array}{l}\text { Haberman and } \\
\text { Danes (2007) }\end{array}$ & $\begin{array}{l}\text { Family Business } \\
\text { Review }\end{array}$ & $\begin{array}{l}\text { Father-Daughter and } \\
\text { Father-Son Family } \\
\text { business Management } \\
\text { Transfer Comparison: } \\
\text { Family FIRO Model } \\
\text { Application. }\end{array}$ & $\begin{array}{l}\text { The article investigates power structures and interactions among father- } \\
\text { daughter and decision teams experiencing management transfer. } \\
\text { Analytical induction was the methodology used. }\end{array}$ \\
\hline $\begin{array}{l}\text { Lewis and } \\
\text { Morgan (1994) }\end{array}$ & Human Relations & $\begin{array}{l}\text { Gendering } \\
\text { organizational change: } \\
\text { the case of Relate, } \\
1948-1990 .\end{array}$ & $\begin{array}{l}\text { Focussing on a single case, the paper develops a gendered understanding } \\
\text { of processes of organisational change. The case of Relate is especially } \\
\text { interesting in that issues of gender inevitably enter into its primary task, } \\
\text { the treatment of marital difficulties, and that as a voluntary organisation } \\
\text { it has employed a high proportion of unpaid women in the key activity } \\
\text { of counselling, while the managerial positions have been dominated by } \\
\text { men. Organisational culture and the gendered metaphors and rhetoric } \\
\text { that are used within the organisation are also shown to be significant. }\end{array}$ \\
\hline Jimenez (2009) & $\begin{array}{l}\text { Family Business } \\
\text { Review }\end{array}$ & $\begin{array}{l}\text { Research on Women } \\
\text { on Family Firms: } \\
\text { Current Status and } \\
\text { Future Directions. }\end{array}$ & $\begin{array}{l}\text { Review of } 48 \text { articles and other research works published since } 1985 . \\
\text { Examines both obstacles and positive aspects of women's involvement in } \\
\text { family firms. Findings that wives play an important role for the } \\
\text { continuity and growth of the family firm and also the factors that can } \\
\text { help or hinder daughters to progress professionally and achieve } \\
\text { leadership positions in this type of firm. }\end{array}$ \\
\hline Melin (2008) & $\begin{array}{l}\text { Book chapter in } \\
\text { Larsson, } \\
\text { Göransson, and } \\
\text { Lagerholm, (Eds), } \\
\text { Sesam öppna dig! } \\
\text { Perspektiv på } \\
\text { kvinnors } \\
\text { företagande. }\end{array}$ & $\begin{array}{l}\text { Ägarskiften genom arv } \\
\text { eller köp - en } \\
\text { möjlighet för kvinnor. }\end{array}$ & $\begin{array}{l}\text { Barriers and conditions for ownership transfers in the future will } \\
\text { probably lead to more women as entrepreneurs. }\end{array}$ \\
\hline $\begin{array}{l}\text { Mulholland } \\
\text { (1996) }\end{array}$ & $\begin{array}{l}\text { Gender, Work and } \\
\text { Organisation }\end{array}$ & $\begin{array}{l}\text { Gender and property } \\
\text { relations within } \\
\text { entrepreneurial wealthy } \\
\text { families. }\end{array}$ & $\begin{array}{l}\text { Data have been drawn from the findings of a study of } 70 \text { rich families in } \\
\text { the Midlands of England, and includes industrial, commercial, landed } \\
\text { and old and new wealth. The paper challenges the popular image of } \\
\text { middle and upper class women as beneficiaries, and consumers of wealth } \\
\text { and correspondingly of men as the central agents in the creation of } \\
\text { wealth. }\end{array}$ \\
\hline $\begin{array}{l}\text { Pettersson } \\
(2008)\end{array}$ & $\begin{array}{l}\text { Book chapter in } \\
\text { Larsson, P., } \\
\text { Göransson, U. and } \\
\text { Lagerholm, M. } \\
\text { (Eds), Sesam } \\
\text { öppna dig! } \\
\text { Perspektiv på } \\
\text { kvinnors } \\
\text { företagande. }\end{array}$ & $\begin{array}{l}\text { Hur påverkas kvinnors } \\
\text { företagande av familj } \\
\text { och privatliv? }\end{array}$ & $\begin{array}{l}\text { How women as entrepreneurs are affected by family and their private } \\
\text { life, and also the horizontal and vertical segregation in the labour market } \\
\text { between women and men is discussed. }\end{array}$ \\
\hline $\begin{array}{l}\text { Salganicoff } \\
(1990)\end{array}$ & $\begin{array}{l}\text { Family Business } \\
\text { Review }\end{array}$ & $\begin{array}{l}\text { Women in Family } \\
\text { Businesses: Challenges } \\
\text { and Opportunities. }\end{array}$ & $\begin{array}{l}\text { Women have particular qualities that can be vital to the survival and } \\
\text { success of a family business. Those who work in and for family } \\
\text { businesses need to be aware, however, of the dilemmas and conflicts that } \\
\text { affect women. }\end{array}$ \\
\hline $\begin{array}{l}\text { Vera and Dean } \\
(2005)\end{array}$ & $\begin{array}{l}\text { Family Business } \\
\text { Review }\end{array}$ & $\begin{array}{l}\text { An Examination of the } \\
\text { Challenges Daughters } \\
\text { Face in Family Business } \\
\text { Succession }\end{array}$ & $\begin{array}{l}\text { Interviews with ten female family business owners. The purpose is to } \\
\text { determine the extent to which daughters face challenges in family } \\
\text { businesses. }\end{array}$ \\
\hline
\end{tabular}


